\title{
New technology, trade unions and the future: not quite the end of organised labour
}

\author{
Nuevas tecnologías, los sindicatos y el futuro: realmente, no es \\ el fin del trabajo organizado
}

\author{
Miguel Martínez Lucio \\ The University of Manchester, England \\ Miguel.MartinezLucio@manchester.ac.uk \\ Stephen Mustchin (i) \\ The University of Manchester, England \\ Stephen.Mustchin@manchester.ac.uk

\section{Stefania Marino} \\ The University of Manchester, England \\ stefania.marino@manchester.ac.uk

\section{Debra Howcroft} \\ The University of Manchester, England \\ debra.howcroft@manchester.ac.uk

\section{Holly Smith} \\ The University of Manchester, England \\ holly.smith-3@manchester.ac.uk
}

Received / Recibido:26/10/2020

Accepted / Aceptado: 17/01/2021

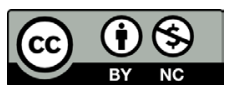

\begin{abstract}
The paper attempts to map some of the more complex interactions between trade unions and the development of new technologies. At a time when trade unions are being seen to be undermined by various developments in the form of the gig economy - and a time when working conditions appear to be deteriorating - we need to review these relations. The more pessimistic narratives, that highlight the inevitable decline of trade union and collective worker influence on the nature and use of new technologies at work, do not always capture the rich tapestry and history of the way workers engage with change. There are various developments that suggest that worker struggles, and engagement, are beginning to broaden and renew themselves in the light of such organisational and technological challenges.
\end{abstract}

Keywords: New technology, work, trade unions, workers organisations

\section{RESUMEN}

El artículo intenta reconstruir algunas de las interacciones más complejas establecidas entre los sindicatos y el desarrollo de las nuevas tecnologías. Es necesario revisar estas relaciones una vez que nos encontramos en un momento considerado como complicado para

*Autor para correspondencia / Corresponding author: Miguel Martínez Lucio, Miguel.MartinezLucio@manchester.ac.uk 
los sindicatos, anteel desarrollo de la denominada gig economy y el deterioro experimentado por las condiciones laborales. Las narrativas más pesimistas, que destacan el inevitable declive de la influencia del trabajador colectivo y los sindicatos sobre la naturaleza y el uso de las nuevas tecnologías en el trabajo, no siempre son capaces de apprehender la forma compleja con la que los trabajadores se han enfrentado históricamente a los cambios. Diversas investigaciones sugieren que las luchas y el compromiso de los trabajadores están comenzando a ampliarse y renovarse a la luz de esos desafíos organizativos y tecnológicos.

Palabras clave: Nuevas tecnologías, trabajo, sindicatos, organizaciones de trabajadores.

\section{INTRODUCTION}

The subject of new technology is expansive and a large part of the problem in relation to its impact on work and employment is the failure to clearly define the actual type and form of new technology being researched (Howcroft and Taylor, 2014). The debate has mutated since the 1970s, when it began to be isolated as a specific 'disrupter', rather than seen as part and parcel of the evolving nature of employment relations. Ongoing questions as to where trade unions fit within the landscape of an increasingly digitalised, automated and information-based economy has led to a range of interventions. The debate on the informational economy, the impact of artificial intelligence and other related developments has tended to sideline concerns with organised labour and questions of employment regulation, leaving them to sub-disciplines that are focused on work and employment, and not appreciating that within these spaces there is a lively and engaging debate on politics and conflicts related to new technology. This paper aims to outline some of the ways in which trade unions and worker organisations more generally (the distinction will become apparent in the paper) have indeed responded to an ongoing set of sociotechnical changes: it does not aim to outline development across all contexts, but to illustrate counter arguments through a range of specific developments so as to suggest that adopting a pessimistic and negative approach that views industrial relations and worker organisations as becoming irrelevant is not advisable. The objective is, therefore, to introduce different dimensions of this debate. While there has always been a pessimistic strand that undervalues the capabilities of trade unions and their strategic possibilities in relation to change, the paper sets out different dimensions of the debate on how trade unions and networks of workers are responding to the introduction of new technology in terms of regulation, bargaining, new forms of mobilisation, new forms of worker organisation, and innovative forms of communication. What is more, the paper argues that there are historical and alternative legacies suggesting that the debate regarding worker 'input' into technological change is much richer and more complex than would at first be imagined within the broader spaces of sociological analysis.

\section{THE FATAL ATTRACTION OF INTELLECTUAL PESSIMISM}

The emergence of 'new' forms of technology and related debates about the gig economy and platform work needs to be approached cautiously, given the tendency to overstate the nature of change at work (Howcroft and Taylor, 2014). The growing interface between information and communications technology, crowdsourcing, robotics and other related developments are perceived to be driving the reshaping of work, though to what extent remains subject to debate. The heterogeneous nature of new technology seems to give rise to divergent perspectives, partly because the potential of such changes are viewed in futuristic frameworks, based on speculation and forecasting rather than empirical evidence which examines actual or immediate effects. It has also spawned an exhaustive debate that has more recently become populated by reams of academics. In the case of 
labour relations or the study of the sociology of work, it has also been paralleled by, and interfaced with, specific discussions regarding the fate of organised labour (one needs to go further than reference the extensive literature on the decline of organised labour: Alonso, 2001; D'Art and Turner, 2002). There was also an element of uncertainty about the role of organised labour in some of the classic and early insights into post-industrialism (see below). The impact of change on better-paid jobs and working conditions has therefore been a concern for some time within a range of discussions (Mahon, 1987).

It is not uncommon for a view to be held that there is a zero-sum game between organised labour and technological change. There are a range of what could be called pessimistic studies, in itself a slightly emotive term, that have seen informational changes as being anathema to trade unions and collectivism. Chaison (2005) argued that there were negative consequences for trade unions as employers used new forms of technology to isolate workers from a collective culture - separating them from collective spaces as well as individualising trade unions from internal company communications with workers, through the intranet, for example. In addition, many of the concerns of the labour movement regarding the use of technology by management to undermine work in many cases form part of a political memory and experience (Mokyr, 1992). This seems to mirror a set of concerns that had emerged previously from discussions of how management, since the 1980s, has been marginalising trade unions through new forms of direct communication and engagement with the workforce (Dundon et al, 2004), with new forms of information technology expanding these possibilities further for management. Furthermore, for some this strategic use of new forms of technology by employers was also built into the very design and nature of it: the class bias of computerisation - and as a part of a combination of changes - had an effect on trade unions and their ability to respond to employers and their agendas (Krystal, 2019). There are countless studies that alert us - and quite rightly - to the negative effects new technology can have on working conditions, and worker voice more generally. However, increasingly we have seen a growing recognition that the ways in which new technology shapes employment relations is complex and ambivalent to say the least, and that we need to be aware of the different forms of technological change and different employment contexts: technology is not a neutral and apolitical development. Compared with earlier understandings, the emergence of new technologies such as advanced robotization, artificial intelligence, and technologically-mediated spatial and organisational forms such as crowdwork, represent a different set of challenges (and indeed possibilities) (see Howcroft and Taylor, 2014; Holtgrewe 2014). These new challenges also coincide with an industrial relations context where there is an uneven mobilisation capacity amongst trade unions across different countries and their ability to respond to economic austerity policies being challenged (Larsson, 2015).

\section{THE ROLE OF TRADITIONAL FORMS OF REGULATION IN MEDIATING TECHNOLOGICAL CHANGE}

Remaining focused on a more generic understanding of the 'new new' technologies (Holtgrewe, 2014) there are clearly contradictions and uneven outcomes. That is not to say the trade union movement is not caught out by the difficult forms of transition at work in relation to the use of various aspects of new technology. In the 'first' round of debates on new technologies at work, trade unions had responded by trying to mediate the introduction and use of technology not solely in terms of pay compensation or limiting the effect on employment. The use of new technology agreements or the extension of collective bargaining into the realm of new technology has been a demand - and to some extent a reality - of trade unions since the 1970s. In 1979, the UK's union confederation, the Trades Union Congress (TUC), argued that management was not to introduce technological change unilaterally, that there would be early discussions and access to relevant information on the subject, that there were commitments to retraining, and that health and safety guidelines would be important (among other principles) 
(Manwaring, 1981). Within various national contexts in Western Europe, there was a range of legislative developments at that time calling on management to give advance notice of the introduction of new technology, and to negotiate the key changes brought by it. There was a general sense that technology agreements and a robust system of collective bargaining would be a way of moderating some of the negative effects of change. Within the Swedish context the culture of social dialogue and aspects of industrial democracy ensured the presence of cases where trade unions were involved to some extent in questions of design and implementation (Bansler, 1989). The role of trade unions in alternative design projects was not unknown within the Scandinavian context (Ehn, 2017). Much of this narrative of how trade unions and workers can play a dynamic role with the development and implementation of new technology illustrates that some of the negative readings of organisational change and worker marginalisation need to be tempered and contextualised historically in terms of a variety of different and innovative developments, no matter how specific. The role of the regulatory context where there is a greater emphasis on collective worker voice, and key themes such as training, can play an important part in shaping technological outcomes (Lloyd and Payne, 2019). That is not to say there have not been concerns with the organisational limitations, resource challenges and political hostility facing trade unions when engaging with such changes (Manwaring, 1981; Thomas, 1991), but alternatives have existed, and may still exist, in relation to the nature of collective bargaining and the role of specific agreements.

\section{THE NEW POLITICS OF MOBILISATION AND TECHNOLOGICAL CHANGE: REFRAMING SYSTEMS OF REGULATION AND RIGHTS}

One cannot deny that the framework and form of regulated industrial relations have been subject to significant pressures, and that we have seen a mutation in the mechanisms outlined earlier that can mediate organisational change and its effects, though overstating the decline of collective bargaining should be cautioned. However, beyond the realm of 'social dialogue' we have seen a new wave of innovation within the trade union movement, broadly speaking, that has both responded to, and harnessed, specific dimensions of the latest developments in new technology, especially as specific types of information technology unsettle the very forms and structures of employment itself, in terms of the gig economy, for example.

Trade unions as well as new forms of worker organisation of a more radical or smallscale nature responding to some of the more bureaucratic legacies and lethargy of established labour organisations have reacted in general terms to the way technological developments are contributing to the fragmentation of the workplace, let alone within it. Stewart and Stanford (2017), in discussing 'crowd work' and 'work on demand' systems in the Australian context have pointed to a variety of strategies that have evolved to counter the negative effects and to challenge the general downgrading of work associated with such developments. They argue that there is a possibility of using existing legal frameworks and litigation strategies in relation to questions of workers' rights in such a new context. The question of how employment and self-employment are classified is another way in which workers can attempt to influence the effects of the gig economy in legal terms. How the concept of 'worker' is defined in relation to their rights and specific categories, such as 'independent workers', has created for them a set of new struggles: before they can even begin to progress with 'normal' trade union organising/campaigns, they have the initial barrier of having to fight for the right to legitimise themselves as workers, both to other labour organisations, and the state, which is important in terms of "representative claims". Indeed, the very nature of the employer and who the employer is needs to be defined in such a way that worker rights and employer responsibilities are not fragmented and diminished. Stewart and Stanford (2017) therefore point to the juridical dimension of the debate regarding regulation as one where the trade union movement is increasingly using new forms of mobilisation in relation to the state. To this 
extent, the terrain of the state in terms of its judiciary has become an ongoing source of engagement by workers and their organisations in challenging the attempts by platform companies such as Uber to mystify (or 'extract themselves' from) the employment relation and thus bypass worker rights. Remaining in the Australian context, there are cases where agreements have been struck between employers and unions in relation to the gig economy where minimum rates of pay, insurance-related issues, and health and safety roles and expectations have been secured (Minter, 2017). To that extent the legacy of technology agreements and the role of bargaining remains a key pivot of these responses. How extensive they are is another matter as trade unions have to continuously push on legal cases and campaigns regarding the relation between workers, work and their employers in a changing technological context.

The use of specific legal decisions and new forms of agreement may be contingent on the extant body of rights. What is more, they are also contingent on new forms of mobilisation. The nature of the gig economy, regardless of the extent of surveillance and direct forms of control through the use of algorithmic management and dispersed location of workers, does expose it to the possibility of disruption. The nature of the short-term or contingent employment contract is such that it is difficult to create a stable relation or nuanced 'psychological contract' between the worker and the supposed employer. In addition, the 'Just in Time' culture of the gig economy, and its very explicit use of customer expectations in terms of time and receipt, particularly with regard to location-based services such as delivery or transportation work, poses the reputation and operations of a firm under significant threat by workers. Based on this vulnerability, there have been a range of responses that have used the brief yet highprofile forms of strikes and public protests developed by various collectives of workers to air their grievances, ensure better working conditions and seek improvements to their employment status. The research institute, the Centre for Employment Relations, Innovation and Change (CERIC) in the UK has begun to map and evaluate the expansive range of mobilisations and industrial conflicts emerging in the gig economy (Joyce et al, 2020). Generally speaking, this dimension of mobilisation is much more important to the modus operandi of the labour relations of the gig economy than was likely to have been the case in the previous scenarios linked to the classic forms of new technology agreements. It has also been linked to a growing plurality in the nature of worker voice and organisation. As well as using established opportunity structures as outlined earlier, and normally followed by more established trade unions, there is also the possibility of grass roots unions following more direct forms of engagement and mobilisation (Vandaele, 2018). These are more likely to use a wide repertoire of forms of collective action (Alberti, 2016). In addition, there are also quasi-unions or guild-like systems emerging in relation to specific types of platform work, especially of a more skilled nature (ibid.). These types of networks can be seen in a range of industries such as game design/development and established media industries (the use of informal networks around labour market information is common in the latter - see Saundry et al., 2007- see also Heckscher and Carré, 2006). Hence, we see not just new forms of mobilisation but also new forms of worker organisation emerging from the struggles around new technology: more established unions tend to see new technology as a tool for communication and engagement whereas new sets of collectives tend to highlight as part of the broadening space of internal dialogue and new spaces for activism (Waterman, 2001). There are interventions that see a tension between more formal and institutionalised trade union approaches and structures, on the one hand, and those emerging 'on the ground' within the gig economy with its more direct and explicit forms of exploitation and marginalisation, on the other. However, there are more complex dynamics at play as each of these constituencies of worker organisations have various internal dynamics that suggest a greater degree of interaction (Neilson, 2018; Smith, 2021). The ways that new organisations of worker voice are evolving - and perhaps jostling with each other - within these new fragmented spaces of the gig economy is an increasing focus of research as the experiences of gig-related workers are fore-fronted 
in a range of debates regarding the innovative aspects of such movements as well as the problems of sustainability (Wood and Lehdonvirta, 2019; Aloisi, 2019).

The use of existing institutional resources and of new forms of engagement and mobilisation, representing the way the nature of trade union engagement works across different forms of solidarity networks and various issues, is expanding. That is to say, the response to new technology is not simply about the form of the technological artefact, but also links to the different employment issues that are emerging as a consequence of technological change. This is clear in the way the structure and form of the employment contract is changing as a result of the use of 'bogus' self-employment by various platform-based companies, the ongoing and intensified abuse of vulnerable workers through bullying and harassment strategies, and the way that questions of stress and mental health emerge related to the use of new technologies and greater surveillance. There is also a growing debate on the impact of new technological developments on workload through work intensification issues (Carter et al., 2011, 2013) which dovetails with general concerns about the abuse of wellbeing as a cover for many of the new forms of exploitation employers are developing (Canbanas and Illouz, 2019). In effect, the content of labour relations is expanding, and the sites of struggle are being transformed (Martínez Lucio, 2020) and this creates a new politics of production (Martínez Lucio and Stewart, 1997).

As well as trade unions and new forms of worker organisation engaging with technological change within and beyond the workplace, and its broad consequences, there are a range of initiatives related to worker organisations using the technologies with the intention of reconfiguring the nature of social and employment-related communication. Around a quarter of a century ago, Lee (1997) argued that the Internet offered an opportunity to the trade union movement as it provided new ways of communicating and mobilising that could counter managers' attempts to control this new form of communication. This seminal text marked the beginning of an extensive debate on how trade unions could use the Internet and new forms of virtual communication in relation to accessing a larger group of workers, and during specific disputes when raising awareness and communicating internationally is key: although the use of counter web-sites and Internet-based communication can be the subject of intense political debate internally (Siefert and Sibley, 2005). For Greene et al. (2003) the Internet permitted new forms of participative trade unionism to counter the lethargy of bureaucracy and institutionalism: the window of opportunity it presented allowed for new forms of union voices to emerge in the most difficult of spaces to organise, and for new forms of worker-oriented dialogue to appear (Diamond and Freeman, 2002). As the Internet and social media developed, the ability to use platforms such as Twitter became an important tool for creating a more participative dialogue and connecting different dimensions of the labour movement (Hodder and Houghton, 2015). What is more, networks of workers engaged in specific industries and sectors could maintain an ongoing dialogue regarding the nature of work and labour market prospects (Saundry et al., 2007). To this extent, sustaining a deterministic and reductionist approach to the impacts of new technology fails to engage with the way those technologies may, in turn, be used and redefined in terms of resisting change and creating forms of resilience amongst workers. However, much of this may depend on the culture and structure of trade unions, and the way they mediate the use of such technologies as either a form of participation or as a form of hierarchical communication (Martínez Lucio et al., 2009). To that extent, the interaction between the trade unions and specific forms of new technology, broadly speaking, are mediated by a set of institutional factors.

The way trade unions are able to engage with the nature of new technologies and contain the way they are undermining the traditional spaces of work and creating a more fragmented labour process and system of employment will depend on the extent and nature of trade union organisations beyond the workplace. Much depends on how trade unions and new forms of worker organisation and voice engage at the community level and 
develop more novel spatial dimensions (for a discussion on the spatial dimension of worker organisations, see Roca and Díaz-Parra, 2020) In many respects we have seen new forms of organisation and mobilisation drawing in local communities in a more dynamic manner. For some time there has been a debate among labour relations academics that 'community unionism' represents a much better way of representing and organising - as well as mobilising - especially for precarious workers decoupled or removed from more traditional workplaces, such as those working on transportation and food delivery platforms. Much of the debate is not focused explicitly on new technology per se, but suggests that new forms of labour organisation will come from the 'outside', e.g. independent worker centres based in local communities, as in the USA (Fine, 2006), general community based strategies and alliances between social movements and unions (Holgate, 2015), and the combination of these with more mainstream strategies and negotiation roles (Johnston and Land-Kazlauskas, 2018). As the development and use of new technology fragments work, the more important these spatial innovations are becoming in the response to developments such as the gig economy. This spatial disaggregation also has a global dimension. We cannot ignore that new forms of working-class politics are emerging in the wake of economic and technological changes in developing countries: the transnational span of control is wider as such technologies facilitate an ongoing internationalisation of production processes (Ness, 2016). Research on new forms of production processes and new forms of work intensification are emerging that suggest a transnational political agenda related to trade unions politics (Chan et al., 2013). There is a growing exchange of experiences about how workers are treated in relation to new technological developments that are deliberated on and learnt from across boundaries. However, as Lobera et al have argued (2020) much may hinge on the overall social responses to technological change and the broader dialogue related to it in society and its constituent actors. To that extent the broad policy and social debate requires greater attention on such matters. Overall trust levels with regards to how society views trade unions - and whether they are actually acknowledged and understood as organisations - may be an important factor.

\section{THE CONTEXT OF TECHNOLOGY AND THE SPACES WITHIN WHICH WORKERS RESPOND}

The diverse impact of sociotechnical change brings to the fore new and different employment issues, as noted earlier, around which unions and workers are mobilising. We are seeing a broader template of union forms and concerns, though there is much internal debate as to which forms of worker representation are better placed and able to represent the ever-diversifying nature of workplace politics (Alberti and Però, 2018) especially given the narrowness of traditional union agendas according to Atzeni (2016). To that extent there is no paucity of debate or critical analysis in discussing the way worker organisations engage with technological and broader social change (Las Heras, 2018). This also challenges the way we understand labour relations, and the way we understand its politics and transitions by considering a more flexible and diverse organisational map in relation to worker organisations.

In addition, the challenge is not solely the differential impact of these changes, but rather the overall economic and regulatory dimensions of change. Developments in 'new' technology - as with all forms of change in organisational terms - occur in the context of financialised business models, a dominant culture of neo-liberalism, an emphasis on outsourcing and fragmented organisations, and ongoing labour market and collective bargaining deregulation (Thompson, 2013). These broader factors shape the nature and use of technology, and the way technology is implemented and used by employers. Hence we must locate the discussion not just in relation to matters of 'technique' and 'responses' in relation to worker organisations, but also on the much broader level of engagement around economic and industrial policy and purpose. The problem is that some of this analysis does not always position discussions in the overarching context of change and relevant debates. 
Moreover, the problems trade unions and worker organisations appear to be facing more generally is not so much the nature of technology - the spatial impact of teleworking or the nature of changing employment status that are emerging from the gig economy - but rather the overarching regulatory context and nature of the state. The undermining of trade unions and collective worker voice has been accelerated by the way collective bargaining has been steadily fragmenting and uncoupling from a more articulate and co-ordinated perspective (Koukiadaki et al., 2016; López-Andreu, 2019). The increasing pressure on sector-level agreements and their ability to address broader sectoral changes is a reality that goes on to weaken the ability to co-ordinate responses to developments such as the status of workers in the gig economy and therefore their working conditions. What is more, though the use of litigation against companies engaged with platform work and the gig economy has been an important part of the repertoire of trade union responses, the unevenness and ambivalence of judicial decisions - and the way they vary across national contexts - presents an ongoing challenge. Whereas governments have made attempts to be reflective of the way the gig economy, and broader forms of technological development, need to be responded to through the use of studies and investigations, these have not necessarily materialised as a strengthening of worker voice and influence (Moore and Newsome, 2019). To that extent, the problem of new technology is embedded within the problem of political economy, and the manner in which the introduction and mediation of technology has excluded workers as a result of the legislative context and increasing ambivalence towards trade unions.

In effect, this means that we do not see a more open and socially innovative and inclusive approach to questions of new technology. So, the focus of discussions is not on how to enhance our working lives, but instead centres on changes in market relations (for a general discussion on such issues of new technology and the framing of our needs see Williams, 2018). However, this perceived distance between workers and citizens on the one hand, and new technologies on the other, is in part emerging from the constraints placed on the nature of worker voice and worker rights in terms of the reach and extent of regulation.

\section{CONCLUSION: BACK TO THE FUTURE?}

As discussed, there is a need to be sensitive in historical terms if we are to appreciate that the experience of technological change differs widely. Gorz (1980: 124) highlighted the "importance of "social experiments" with new ways of living together, consuming, producing and cooperating... while at the same time increasing the autonomy of individuals and local communities'. Furthermore, during the period when Gorz was writing, those parts of Europe with stronger systems of worker rights witnessed greater attention to industrial democracy and alternative approaches to technological engagement and codesign. These alternative moments are key to reimagining what unions can do, though some commentators argued that Gorz saw fewer possibilities for working class politics in this new context (Hyman, 1983).

Even if some experiments were short-lived, the role of trade unions was pivotal to a range of initiatives (Hammarström and Lansbury, 1991). The reality is that new technology is socially and politically mediated: it does not have its own 'inner logic' that develops in a direction of its own, but depends on the interplay of various factors for its deployment (Wilkinson, 1983). The regulatory environment is therefore important for unions, and citizens more generally, in framing the decision-making processes regarding the design, production and utilisation of new technology (Lloyd and Payne, 2019). Hence, looping right back to the early debates of a pessimistic nature discussed at the start, we should not forget or ignore alternative interventions and realities with regard to the progressive use and design of technology and the roles that workers, co-operatives and trade unions can play (Graham and Wood, 2016; Scholz, 2016). However, it needs to be said that much 
of the new wave of interest in alternative responses and worker initiatives of a more proactive and engaging nature are pessimistic regarding the ability of national or formal trade union structures and institutional state relations to reproduce the more innovative approaches of previous years. That trade unions are engaging and mobilising in relation to new technology and its effects is clear, but whether they are being supported in socially reimagining it is another matter as new technology is implemented in a chaotic and decentred economic and organisational context. The ability to respond proactively may therefore rest in a broader approach to what we mean by worker voice and engagement (Dundon, et al, 2020).

\section{REFERENCES}

Alberti, G. (2016). Mobilizing and bargaining at the edge of informality: The ' 3 Cosas Campaign' by outsourced migrant workers at the University of London. Journal of Labor and Society, 19(1), 81-103. https://doi.org/10.1111/wusa.12228

Alberti, G., \& Però, D. (2018). Migrating industrial relations: Migrant workers' initiative within and outside trade unions. British Journal of Industrial Relations, 56(4), 693-715. https:// doi.org/10.1111/bjir.12308

Aloisi, A. (2019). Negotiating the digital transformation of work: Non-standard workers' voice, collective rights and mobilisation practices in the platform economy. EUI: EUI Working Paper MWP 2019/03 (available online). https://dx.doi.org/10.2139/ssrn.3404990

Alonso, L. E. (2001). New myths and old practices: Postmodern management discourse and the decline of Fordist industrial relations. Transfer: European Review of Labour and Research, 7(2), 268-288. https://doi.org/10.1177\%2F102425890100700210

Atzeni, M. (2016). Beyond trade unions' strategy? The social construction of precarious workers organizing in the city of Buenos Aires. Labor History, 57(2), 193-214.

Bansler, J. (1989). Trade unions and alternative technology in Scandinavia. New technology, work and employment, 4(2), 92-99. https://doi.org/10.1111/j.1468-005X.1989.tb00107.x

Canbanas, E. \& Illouz, E. (2019) Happycracia. Barcelona: Paidós.

Carter, B., Danford, A., Howcroft, D., Richardson, H., Smith, A. \& Taylor, P. (2011). 'All they lack is a chain': Lean and the new performance management in the British civil service'. New Technology, Work and Employment, 26(2), 83-97. https://doi.org/10.1111/j.1468005X.2011.00261.X

Carter, B., Danford, A., Howcroft, D., Richardson, H., Smith, A. \& Taylor, P. (2013). 'Stressed out of my box': Employee experience of lean working and occupational ill-health in clerical work in the UK public sector. Work, Employment and Society, 27(5), 747-767. https://doi. org/10.11772F0950017012469064

Chaison, G. (2005). The dark side of information technology for unions. WorkingUSA, 8(4), 395-402. https://doi.org/10.1111/j.1743-4580.2005.00025.X

Chan, J., Pun, N. \& Selden, M. (2013). The politics of global production: Apple, Foxconn and China's new working class. New technology, work and employment, 28(2), 100-115. https:// doi.org/10.1111/ntwe.12008

D'Art, D. \& Turner, T. (2002). The decline of worker solidarity and the end of collectivism? Economic and Industrial Democracy, 23(1), 7-34. https://doi.org/10.11772F0143831X02231002 
Diamond, W. J., \& Freeman, R. B. (2002). Will unionism prosper in cyberspace? The promise of the Internet for employee organization. British Journal of Industrial Relations, 40(3), 569596. https://doi.org/10.1111/1467-8543.00247

Dundon, T., Martínez Lucio, M., Hughes, E., Howcroft, D., Keizer, A., \& Walden, R. (2020). Power, Politics and Influence at Work. Manchester: Manchester University Press.

Dundon, T., Wilkinson*, A., Marchington, M., \& Ackers, P. (2004). The meanings and purpose of employee voice. The International Journal of Human Resource Management, 15(6), 11491170. https://doi.org/10.1080/095851904100016773359

Ehn, (2017) Learning in participatory design as I found it (1970-2015) In B, DiSalvo, J, Yip, E. Bonsignore, C. DiSalvo (Eds) Participatory Design for Learning: Perspectives from Practice and Research. London: Routledge

Fine, J. R. (2006). Worker Centers: Organizing Communities at the Edge of the Dream. Ithaca, NY: Cornell University Press.

Gorz, A. (1980). Farewell to the Working Class: An Essay on Post-Industrial Socialism. London: Pluto Press

Graham, M. \& Wood, A. (2016). Why the digital gig economy needs co-ops and unions. Open Democracy. https://www.opendemocracy.net/alex-wood/why-digital-gig-economyneeds-co-ops-and-unions.

Greene, A. M., Hogan, J. \& Grieco, M. (2003). Commentary: E-collectivism and distributed discourse: New opportunities for trade union democracy. Industrial Relations Journal, 34(4), 282-289. https://doi.org/10.1111/1468-2338.00275

Heckscher, C. \& Carré, F., 2006. Strength in networks: Employment rights organizations and the problem of co-ordination. British Journal of Industrial Relations, 44(4), 605-628. https:// doi.org/10.1111/j.1467-8543.2006.00516.x

Holgate, J. (2015). Community organising in the UK: A'new' approach for trade unions? Economic and Industrial Democracy, 36(3), 431-455. https://doi.org/10.11772F0143831X13511275

Holtgrewe, U. (2014). New new technologies: the future and the present of work in information and communication technology. New technology, work and employment, 29(1), 9-24. https://doi.org/10.1111/ntwe.12025

Hammarström, O. \& Lansbury, R. D. (1991). The art of building a car: the Swedish experience re-examined. New Technology, Work and Employment, 6(2), 85-90. https://doi.org/10.1111/ j.1468-005X.1991.tb00134.X

Howcroft, D., \& Taylor, P. (2014). 'Plus ca change, plus la meme chose': researching and theorising the new, new technologies. New Technology, Work and Employment, 29(1), 1-8. https://doi.org/10.1111/ntwe.12026

Hodder, A. \& Houghton, D. (2015). Union use of social media: A study of the University and College Union on Twitter. New Technology, Work and Employment, 30(3), 173-189.

Hyman, R. (1983). Andre Gorz and his disappearing proletariat. Socialist Register, 20(20). 272295. https://socialistregister.com/index.php/srv/article/view/5501

Johnston, H. \& Land-Kazlauskas, C. (2018). Organizing on-demand: Representation, voice, and collective bargaining in the gig economy. Conditions of Work and Employment Series No. 94. Geneva: ILO.

Joyce, S., Neumann, D., Trappmann, V. \& Umney, C. (2020). A Global Struggle: Worker Protest in the Platform Economy. ETUI Research Paper-Policy Brief, 2. 
Koukiadaki, A., Távora, I. \& Martínez Lucio, M. (2016). Continuity and change in joint regulation in Europe: structural reforms and collective bargaining in manufacturing. European Journal of Industrial Relations, 22(3), 189-203.

Kristal, T. (2019). Computerization and the Decline of American Unions: Is Computerization Class-Biased? Work and Occupations, 46(4), 371-410.

Larsson, B. (2015). Trade union channels for influencing European Union policies. Old site of Nordic Journal of Working Life Studies, 5(3), 101-121. https://gup.ub.gu.se/ publication/175062

Las Heras, J. (2018). International political economy of labour and collective bargaining in the automotive industry. Competition \& Change, 22(3), 313-331. https://doi. org/10.11772F1024529418764350

Lee, E. (1997). Labour and the Internet: The new internationalism. London: Pluto Press

Lloyd, C. \& Payne, J. (2019). Rethinking country effects: Robotics, Al and work futures in Norway and the UK. New Technology, Work and Employment, 34(3), 208-225. https://doi. org/10.1111/ntwe.12149

Lobera, J., Fernández Rodríguez, C. J. \& Torres-Albero, C. (2020). Privacy, values and machines: Predicting opposition to artificial intelligence. Communication Studies, 71(3), 448-465. https://doi.org/10.1080/10510974.2020.1736114

López-Andreu, M. (2019). Neoliberal trends in collective bargaining and employment regulation in Spain, Italy and the UK: From institutional forms to institutional outcomes. European Journal of Industrial Relations, 25(4), 309-325. https://doi.org/10.11772F0959680118810294

Mahon, R. (1987). From Fordism to?: New technology, labour markets and unions. Economic and Industrial Democracy, 8(1), 5-60. https://doi.org/10.1177\%2F0143831X8781002

Manwaring, T. (1981). The trade union response to new technology. Industrial Relations Journal, 12(4), 7-26. https://doi.org/10.1007/978-1-349-06089-4_12

Martínez Lucio, M. (2020) Trade unions and stress at work: The evolving responses and politics of health and safety strategies in the case of the United Kingdom. In R. J. Burke and S. Pignata (Eds), The Handbook of Stress and Wellbeing in the Public Sector (pp. 15-32). Cheltenham: Edward Elgar.

Martínez Lucio, M. \& Stewart, P. (1997). The paradox of contemporary labour process theory: The rediscovery of labour and the disappearance of collectivism. Capital \& Class, 21(2), 49-77. https://doi.org/10.1177\%2F030981689706200104

Martínez Lucio, M., Walker, S. \& Trevorrow, P. (2009). Making networks and (re) making trade union bureaucracy: A European-wide case study of trade union engagement with the Internet and networking. New Technology, Work and Employment, 24(2), 115-130. https:// dx.doi.org/10.1111/j.1468-005X.2009.00223.x

Minter, K. (2017). Negotiating labour standards in the gig economy: Airtasker and Unions New South Wales. The Economic and Labour Relations Review, 28(3), 438-454. https://doi. org/10.11772F1035304617724305

Mokyr, J. (1992). Technological Inertia in Economic History, The Journal of Economic History, 52(2) 325-338.

Moore, S. \& Newsome, K. (2019). Management by exception? The Taylor Review and workforce management: Good Work: The Taylor Review of Modern Working Practices, reviewed by Sian Moore and Kirsty Newsome. New Technology, Work and Employment, 34(2), 95-99. https://doi.org/10.1111/ntwe.12128 
Ness, I. (2016) Southern Insurgency: The Coming of the Global Working Class. London: Pluto Press.

Neilson, T. (2018). Unions in digital labour studies: A review of information society and Marxist autonomist approaches. tripleC: Communication, Capitalism \& Critique, 16(2), 882-900. https://doi.org/10.31269/triplec.v16i2.1065

Roca, B. \& Díaz-Parra, I. (2020). Spatial perspectives on labor and social movements: Multidisciplinary dialogues and dilemmas. Sociology Compass, e12845. https://doi. org/10.1111/soc4.12845

Seifert, R. \& Sibley, T. (2005). United They Stood: The Story of the UK Firefighters' Dispute 20024, Lawrence \& Wishart: London

Smith, H. (2021). The 'indie unions' and the UK labour movement: Towards a community of practice. Economic and Industrial Democracy. https://journals.sagepub.com/doi/ full/10.1177/0143831X211009956

Saundry, R., Stuart, M. \& Antcliff, V. (2007). Broadcasting discontent - freelancers, trade unions and the Internet. New Technology, Work and Employment, 22(2), 178-191. https://doi. org/10.1111/j.1468-005X.2007.00192.x

Scholz, T. (2016). Platform cooperativism: Challenging the corporate sharing economy. New York, NY: Rosa Luxemburg Foundation.

Stewart, A. \& Stanford, J. (2017). Regulating work in the gig economy: What are the options? The Economic and Labour Relations Review, 28(3), 420-437. https://doi. org/10.11772F1035304617722461

Thomas, R. J. (1991). Technological choice and union-management cooperation. Industrial Relations: A Journal of Economy and Society, 30(2), 167-192. https://doi.org/10.1111/j.1468232X.1991.tb00784.x

Thompson, P. (2013). Financialization and the workplace: Extending and applying the disconnected capitalism thesis. Work, Employment and Society, 27(3), 472-488. https:// doi.org/10.11772F0950017013479827

Vandaele, K. (2018). Will trade unions survive in the platform economy? Emerging patterns of platform workers' collective voice and representation in Europe. ETUI Research Paper/ Working Paper, 19 June.

Waterman, P. (2001). Trade union internationalism in the age of Seattle. In P. Waterman \& J. Wills (Eds), Place, Space and New Labour Internationalisms (pp. 8-32), Blackwell, Oxford, Malden MA.

Williams, J. (2018). Stand Out of Our Light: Freedom and Resistance in the Attention Economy. Cambridge: Cambridge University Press.

Wilkinson, B. (1983) The Shopfloor Politics of New Technology. Farnham, UK: Gower.

Wood, A. J., Lehdonvirta, V. \& Graham, M. (2018). Workers of the Internet unite? Online freelancer organisation among remote gig economy workers in six Asian and African countries. New Technology, Work and Employment, 33(2), 95-112. https://doi.org/10.1111/ ntwe.12112

Wood, A. \& Lehdonvirta, V. (2019). Platform labour and structured antagonism: Understanding the origins of protest in the gig economy. Working Paper presented at the Oxford Internet Institute Platform Economy Seminar Series March 5th 2019 https://dx.doi.org/10.2139/ ssrn.3357804 